\title{
Sexual Practice and Fantasy in Colonial America and the Early Republic \\ Richard Solomon
}

Graduate Mentor: Rafael Khachaturian, Department of Political Science Indiana University

KEYWORDS: colonial America, sexual practice, fantasy, colonial society

$\mathrm{T}_{\mathrm{b}}^{\mathrm{h}}$ The modern academic study of sexuality has proven to be a potent tool for describing historical and political relationships between groups of people. "By historicizing matters once understood as universal and eternal, scholars of sexuality have connected sexual behaviors and desires to specific political, social, and economic contexts." Building upon this literature, I will argue that the ostensibly private realm of sex is inextricably intertwined with the racial, religious, and economic forces of a time period. The sexual practices of European colonists, Native Americans, and African-American slaves of the American colonies and early republic reflected economic and religious disparities, providing specific cultural phenomena upon which power relations were established and reaffirmed. These hierarchies not only prescribed the role of sex in quotidian American life; they created lasting traditions in sexual practices that continue to the present day.

For this thesis, I rely on contemporary and classic historiography, religious studies, and gender scholarship to make claims about the role of women in colonial society and the treatment and fantasy-construction of marginalized peoples: namely, African-American slaves and Native Americans. Specifically, I will show how colonial women leveraged their scarcity and sexual desirability to secure their gender's procreative role and social utility in Puritan and Southern colonies. I will show how national myths of manifest destiny and the fecundity of the land came to dominate whites' experience of Native American sexuality, how the formation and subjugation of the Black slave class acquired distinct and lasting sexual fault lines, and finally how political pressures and economic incentives to justify slavery nurtured whites' sexual attitudes and behavior toward Blacks. I hope to synthesize these discussions with explorations of their role in shaping contemporary sex relations and the underlying ways these dimensions impacted everyday life in the American colonies and early Republic.
Colonial structures refracted and channeled sexual practice and fiction. As Michael Foucault reminds us, "Sexuality was 'a result and an instrument of power's design,' a social construction of a historical moment (The History of Sexuality: 152). For Foucault, sexuality is not opposed to and subversive of power. On the contrary, sexuality is a 'dense transfer point' of power, charged with "instrumentality."'2 As Edward Said and Foucault remind us, knowledge production and behavior are products of political hierarchies and imperial legacy. ${ }^{3}$ In this way, historical analysis of family politics, class divisions, and national myths provide important insights into the history of American sexuality.

Academic scholarship of colonial America has begun to provide a compelling alternative to H.L. Mencken's stereotypical Puritan as tortured by the fear that "someone, somewhere, may be happy." ${ }^{4}$ Recent literature points to a diverse and complex system of sexual and family politics, giving support to the idea that "the once stark portrait of Massachusetts Bay as an austere religious community devoid of women's authority and sexual diversity-or even of sexually active married individuals" is too simplistic an account. ${ }^{5}$ The object of draconian sex laws was deviant practices, for which colonial society allocated a realistic possibility of repentance and reintegration. In contrast, the realm of the bedroom (or, the common room in early colonial structures) remained under the command of the married couple, who privately decided their sexual habits.

In contrast to previous assertions of Puritan life, individuals and sexual deviants could be reintegrated into colonial life and social standing if they successfully repented. In 1650, a young man Samuel Terry of Springfield, Massachusetts was found "chafing his yard to provoak lust" outside the church meetinghouse. The authorities lashed and fined him for public masturbation, but he broke the rules again by having premarital sex with his fiancé in 1661, and found himself again fined in 1673 for "immodest and beastly" activity with other
${ }^{1}$ Sharon Block and Kathleen M. Brown. "Clio in Search Eros: Redefining of Sexualities in Early America." William and Mary Quarterly 60, no. 1 (2003): 6.

\footnotetext{
${ }^{2}$ Ann Laura Stoler, Race and the Education of Desire: Foucault's History of Sexuality and the Colonial Order of Things. (Durham, North Carolina: Duke University Press, 1995), 3.

${ }^{3}$ Edward Said, Culture and Imperialism. (New York: Random House, 1993), 3-18.

${ }^{4}$ John Emilio and Estelle B. Freedman, Introduction to Intimate Matters: A History of Sexuality in America. (New York: Harper \& Row, 1988).

${ }^{5}$ Sandra Slater, "Sex and Sin: The Historiography of Women, Gender, and Sexuality in Colonial Massachusetts.” Historical Journal of Massachusetts 41, no. 1 (2013): 105.
} 
men. ${ }^{6}$ By all classical characterizations of Puritan society, Terry would be an outcast and possibly incarcerated. Yet he defied the stereotype and lived on to serve as a town constable, respected by his fellows, and was even given custody by a town court over another man's infant. ${ }^{7}$ Puritan society was lenient in this way, allowing someone who accepted punishment for his sins to continue as a respected citizen. To outcast him or exclude him from a productive capacity made him a burden to another breadwinner and posed an anomaly to the Puritan vision of the family. This is not to say laws were not draconian, but does suggest there were economic and social incentives for keeping such moral codes.

Men generally, in their role as breadwinners, profited from the procreative sexual norms of the day. Agricultural economies demanded children, illustrated in the New England laws against "solitary living." ${ }^{8}$ These economies created stable societal units to ensure economic survival and provided the primary context in which youth were indoctrinated about how to view and limit sexual activity. The model of the family as the central economic unit necessarily problematized divorce, "idle" or single life, and children born out of wedlock. To prevent these issues, Puritan codes restricted sex to marital relations, incentivized women to stay in marriages, and minimized the ostracism of repentant individuals all to keep people within the family fold. "Colonies passed bastardy laws, patterned upon English antecedents, that severely punished the parents of bastards and attempted to hold the purported father responsible for the child's care."9 Consequently, New England had lower bastardy rates compared to the old South. ${ }^{10}$

High mortality rates made remarriage common and encouraged. Numbers of offspring were large. For example, John Winthrop, author of City upon a Hill, had sixteen children with four different wives. In the case of widows, the prospect of remarriage presented economic opportunities to colonial males. Unique "conduits of wealth and land, and with high mortality rates prevailing throughout the seventeenth century," colonial women were made objects of male competition, both as status symbols for the landed elite and as a means to land ownership for indentured servants in the south. ${ }^{11}$ Agricultural labor demanded a steady supply of offspring, subject to strict supervision by society and family, lest they endanger their father's inheritance. To this end, Puritans delegated to parents the responsibility to "breed \& bring up children \& apprentices in some honest Lawfull calling." ${ }^{12}$ Children were expected to remain under their parent's supervision until marriage, and until that time they worked long hours. In these ways, puritan family structures were a far cry from the modern American nuclear family.

From this context, colonial women from New England areas used their capacity to rarify or scarify the resource of sex-by discouraging sex out of wedlock, before marriage, and out of pleasure-not simply out of religious compunction but for real economic incentive to augment the social value of their own motherhood and gender in a world dominated by male-oriented channels of accomplishment. This argument comes as a cross-application of Kristen Luker's Abortion and the Politics of Motherhood in which she demonstrates that contraception and abortion devalue the security of pro-life social location and resource availability; they collapse the sanctity of the private world of home and hearth in a loss that pro-choice women can afford because of their status in other realms. To pro-life women, and as I will argue for colonial-era women, an attitude that liberalizes sex undercuts access to worth. In their perceptions, liberal sexual attitudes limited women's ability to be married in the first place and undermined its procreative function within marriage. ${ }^{13}$ Such a theory for sexual relations assumes the following:

1. Women were restricted from the same level of social and economic mobility that men had. Such is the case for Luker's pro-life, anti-abortionists whom she demonstrates to have dramatically lower levels of education and income while simultaneously high rates of children. Colonial women-who had virtually zero economic or social status outside of a family unit or marriage-can be counted in this category.

2. The primacy of the women's reproductive role is taken for granted and socially encouraged. Colonial women acknowledged the sacred value of motherhood, in accordance with Calvinist theology.

3. Anything to diminish or undermine the role of motherhood and married women as the exclusive sexual outlet diminishes the value of women married and aspiring to be. Women experience and respond positively to economic incentive to augment their own value as much as anyone else.

4. To relocate the purpose of sexuality as non-procreative and instead for amative intimacy and pleasure effectively downgrades the sacred place of the woman as mother and child-rearer. In addition, a sexual outlet

\footnotetext{
${ }^{6}$ Stephen Innes, Labor in a New Land Economy and Society in

Seventeenth-Century Springfield. (Princeton: Princeton University Press, 2014), 132-133.

Emilio and Freedman, Intimate Matters, 15.

${ }^{8}$ K. Kelly Weisberg, “'Under Greet Temptations Heer' Women and Divorce in Puritan Massachusetts." Feminist Studies, 2 (1975): 183-193.

${ }^{9}$ Emilio and Freedman, 32.

${ }^{10}$ Ibid.

${ }^{11}$ Nancy Isenberg, White Trash: The 400-Year Untold History of Class in America. (New York: Random House, 2016). 37.
}

${ }^{12}$ Christopher L. Tomlins, Freedom Bound. Law, Labor, and Civic Identity in Colonizing America, 1580-1815 (Cambridge: Cambridge University Press, 2010). 307-310.

${ }^{13}$ Kristin Luker, Abortion and the Politics of Motherhood (Berkeley: University of California Press, 1984), 158-215. 
outside the religious parameters of marriage-such as masturbation, prostitution, or homosexualitythreatens the woman's social value in society.

5. Conversely, "Anything that supports a traditional division of labor into male and female worlds is in the interests of pro-life [colonial] women because that is where their resources lie."14 To rarify the availability of sex augments its worth.

Therefore, we may predict societal pressures to limit sexual outlets outside of marriage, punish and shame offenders, and encourage women to have children as their productive function. Contemporary historiography accounts confirm these predictions. The procreative role did assume primacy: "Regional differences notwithstanding, by the early eighteenth century, sexual practice and sexual meaning were clearly situated within marriage, and the goal of sexuality was procreation." ${ }^{15}$ As in the case of most preindustrial societies, "the family quickly became the central economic unit in every American colony," and "most women assumed that childbearing was their natural calling." 16

Women did contribute to a culture of shaming lewd behavior. Neighbors "cursed women with epithets such as whore, adulteress, slut, or "brasen-faced bawd." 17 In one instance, a Massachusetts woman spat a "slanderous comment at a couple, claiming that "the wife was a whore and that shee had several children by other men, and that Cuckolday old Rogue her husband owned [acknowledged] them." ${ }^{18}$ Even Nathaniel Hawthorne's novel The Scarlet Letter set in seventeenth-century Boston alludes to and employs public shaming of illegitimate or deviant sexual acts (such as adultery) as a central plot device. His audience took for granted shaming as a part of Puritan culture. As an archetypal example of female-to-female normativity policing, the mass hysteria of the Salem witch trials has sexual readings. ${ }^{19}$

Legal statutes permitted women to divorce their husbands if they failed to perform their conjugal duty whether by impotency or sloth, underscoring the centrality of the procreative bond and the legal encouragement of women's value as a reproductive channel. Women responded positively to this. In 1689, a Plymouth wife testified in court that "her husband was always unable to perform the act of generation," justifying her filed divorce. Contraceptive habits were grounds for divorce, "as in the case of Abigail Emery, who in 1710 complained that her husband practiced the 'abominable' sin of Onan (withdrawal) because "he feared the charge of children."'20
Such a success for women on policing and restricting access to sex in New England undoubtedly advanced prevailing religious morals of the time. Public church morality and revivalist rhetoric, such as from Cotton Mather and Thomas Shephard, warned against "inordinate affection" in the bedroom. Church courts had the authority to prescribe lashings, public stockings, and in some cases execution for such members of the community who violated laws against masturbation, premarital sex, and bestiality. Clergy were quick to emphasize the chastity of women and warn of the danger of "sensual lusts, wantonness and impurity, boldness and rudeness, in Look, Word or Gesture."21 European Protestant thought, although contiguous to its American counterpart, did not go to such degrees. Settlers representing "civilization" compensated for the sodomized chaos they perceived around them "by creating excess of order, based on an ideal of extreme social cohesiveness and the practice of close surveillance of personal morality." ${ }^{22}$ Membership to the privileged religious "Elect" was also guarded through sexuallytransferred heritage. Under Reverend Increase Mather, the son of the famous preacher Cotton Mather, "God "cast the line of Election' so that it passed 'through the loins of godly Parents.'...by celebrating lineage, the visible saints became a recognizable breed." ${ }^{3}$

In juxtaposition to the Massachusetts colony, the Chesapeake areas of Maryland and Virginia in the early to middle seventeenth-century provide another instance in which sexual circumstances were also used to increase social value. Southern colonies experienced a much higher sex ratio of indentured servants to women; during the first generations of Chesapeake settlement, male to female ratios were roughly 4:1 while their New England counterparts were a more even $3: 2{ }^{24}$ With the absence of New England-like family stability and a plentitude of male indentured servants,

the skewed ration in the Chesapeake delayed or prevented marital sexual relations, [and] pre- and extramarital sexuality seem to have been more common...Single women in the southern colonies were in such high demand as wives that they may have been less concerned about guarding their virginity than women in England or the Puritan settlements. ${ }^{25}$

Such an anomaly to the formula (family and motherhood $=$ the seat of women's power) elaborates and confirms the original thesis. When women were allowed a means to develop valuation as sexual beings outside the parameters of

\footnotetext{
${ }^{14}$ Ibid., 200.

${ }^{15}$ Emilio and Freedman, 14.

${ }^{16}$ Ibid., 16, 25.

${ }^{17}$ Ibid., 17.

${ }^{18}$ Ibid., 18.

${ }^{19}$ See Tracy Fessenden, The Puritan Origins of American Sex: Religion, Sexuality, and National Identity in American Literature (New York: Routledge, 2001). And Robert Detweiler, "Shifting Perspectives on the Salem Witches." The History Teacher 8 (1975): 596-610.

${ }^{20}$ Emilio and Freedman, Intimate Matters, 26.
}

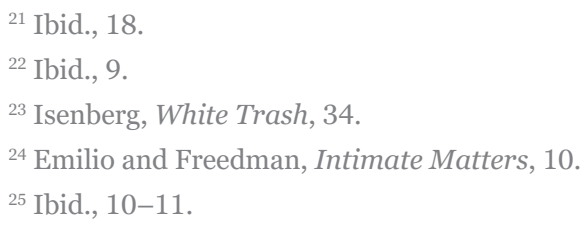


procreative marriage-due to sheer male competition-sexual norms relaxed. Women could be less worried about preserving their virginity. Nuptial pregnancy rates-those children born in wedlock but conceived before it-were more than three times as high in the Chesapeake as in New England. Marriage rejections by females were higher than in the north. Sexual crime laws were more relaxed, and the dispersed nature of populations over farms and plantations made the threat of neighborly surveillance less of a salient fear to young couples. ${ }^{26}$ "Knowing that they could easily remarry, Chesapeake-area women could be tempted by the advances of men other than their spouses, while husbands might well suspect that single men had designs upon their wives." ${ }^{27}$ The greater number of unattached men "meant that southern women had more opportunities for contact with single men," and so women could pursue sex for romantic and erotic purposes. ${ }^{28}$

Women were also sought simply for their fertility. As England shipped off its "waste people" and "disposables" to work off their debts in the labor plantations of the American south, a unique white caste took hold, premised on their collective inability to produce heirs and secure access to land ownership. Women and children presented a way out of debt slavery. So much so, that writing in 1660 Maryland, former indentured servant George Alsop could claim bluntly that women fresh off the boats would "market their virginity" and sell "their breeding capacity of wealthy husbands." ${ }^{29}$ Perhaps most telling, during Bacon's Rebellion of 1676 against Jamestown and its governor William Berkeley, "Bacon rounded up the wives of Berkeley supporters-his phalanx of 'white aprons'-to guard his men while they dug trenches outside the fortified capital of Jamestown...They were too valuable a resource for either side to waste." ${ }^{30}$ In these ways, women developed sexuality as a mechanism to augment and promote their social value. Law and religion manifested the economic incentives of agricultural production, both for colonial women who sought to augment their social value as mothers and for southern women who had the chance to escape the restrictions of procreation and pursue a more amative discourse.

Native American sexual practices and gender conceptions differed widely from European colonists and sometimes from one another. Westerners had difficulty relating such a gender status as the berdache or the practice of polygamy to their own binary and "civilized" conceptions, and this cognitive

\footnotetext{
${ }^{26}$ Mary Beth Norton, "Gender and Defamation in Seventeenth-Century Maryland.” William and Mary Quarterly, 43 (1987): 3-39.

${ }^{27}$ Emilio and Freedman, 10.

${ }^{28}$ Ibid., 11.

${ }^{29}$ Isenberg, White Trash, 36.

${ }^{30}$ Ibid., 39.
}

dissonance facilitated the spread of militant evangelism and encouraged the impulse to 'civilize' or tame the native. The contrast between their sexual systems allowed Europeans to ignore "more similarities within their sexual systems than [they] cared to recognize," ${ }^{31}$ such as the rare use of contraception and the typicality of exclusive, heterosexual unions. European colonists capitalized on lascivious, alluring, and dangerous characterizations of American natives by framing expansionist policy as civilizing missions. To use Rudyard Kipling's phrase, the "White Man's Burden" became an unquestioned truism of the European and colonial ethic, supported by "the authorized monuments of nineteenth-century European culture, the inferiority of non-white races, the necessity that they be ruled by a superior race, and their absolute unchanging essence."32

At the same time that "reports of Indian depredations and savagery...became a means of justifying white misbehavior and atrocities," 33 Western accounts developed ambivalent, wistful attitudes toward what was seen as a fading Native culture. These Western narratives characterized the "good" Indians as "courteous, and hospitable to the initial invaders of his lands and to all Whites....Along with handsomeness of physique and physiognomy went great stamina and endurance....Modest in attitude...Brave in combat, he was tender in love for family and children." ${ }^{34}$ These strong, stoic representations were captured in the image of the Noble Savage and the Vanishing Native, as immortalized in the James Fenimore Cooper's 1826 novel, The Last of the Mohicans, and embodied in the historical figure of Squanto.

Anthropologists have difficulty reconstructing reliable ethnographies of actual Native American sexual life due to a paucity of historical evidence, the sheer variety of native customs, and undocumented cultural destruction. ${ }^{35}$ As well, Native American traditions were in flux over the 200 years between 1600 and 1800, in the same way European sexuality was, making it difficult to pinpoint specific continuities. However, in comparison to the white settlers, some generalities are well established.

"Most native peoples did not associate either nudity or sexuality with sin" in the same way European institutions and Christian theology suggested. ${ }^{36}$ "Reproductive functions rarely evoked shame or guilt for Indian men or women. Many native American tribes accepted premarital intercourse, polygamy and institutionalized homosexuality" and even ascribed spiritual or shamanistic value to such encounters. ${ }^{37}$

\footnotetext{
${ }^{31}$ Emilio and Freedman, Intimate Matters, 8.

${ }^{32}$ Edward Said, Culture and Imperialism, 151

${ }^{20}$ Emilio and Freedman, Intimate Matters, 26

${ }^{33}$ Joane Nagel, Race, Ethnicity, and Sexuality: Intimate Intersections, Forbidden Frontiers (New York: Oxford University Press, 2003), 75.

${ }^{34}$ Nagel, 72. See Davis, Jack L., and Robert F. Berkhofer. "The White Man's Indian: Images of the American Indian from Columbus to the Present.” American Indian Quarterly, 28.

${ }^{35}$ Serena Nanda, Gender Diversity: Crosscultural Variations (Prospect Heights, Illinois: Waveland Press, 2000), 13.

${ }^{36}$ Emilio and Freedman, Intimate Matters, 7.

${ }^{37}$ Ibid.
} 
The fluidity with which men could chose sexual partners also extended to women and youth. "Children grew up with few restrictions on sexual experimentation, which might range from masturbation to sexual play between same-sex or opposite-sex partners. ${ }^{38}$ Such freedoms differed dramatically from the European colonists' experience, both indentured servants and New England Puritans; a white man found cheating on his wife could expect admonishments, possibly fines, or a night in the stocks. A woman of his standing could be flogged or divorced, effectively ending her economic viability.

The communitarian organization of native cultures facilitated a collective conception of family, allowing male and female members to explore extramarital and nonreproductive relationships with a degree of laxity not afforded to the Europeans. When a French Jesuit criticized such relationships on the grounds that a man could not determine "that his son was...his son," a Montagnais man (of upper Quebec) could say with assurance, "You French people love only your own children, but we all love all the members of our tribe." ${ }^{39}$ Such a retort underscores the collectivist culture that allowed such sexual tolerance. These contrary cultural attitudes on sex and property precluded a great deal of sexual conflict. Marital discord was solved by "simply separating and forming new unions, without penalty, stigma, or property settlements." ${ }^{40}$ Prostitution-with its assumptions of ownership and exchange-did not exist as an institution prior to its introduction by European settlers. ${ }^{41}$ In contrast, the rigidity of Puritan formulas of marriage produced a remarkable similarity to sustained relationships of prostitution: a wife provided sex and children and in exchange, the husband provided a livelihood and social standing.

Even rape found little prevalence in cultures unaccustomed to the idea of "taking" someone's virginity or sexual integrity. Although "one of the few sexual acts forbidden by Indian cultures," rape did not quite occupy the same revered place in the listings of fears and brutalities as the Westerners had imagined. ${ }^{42}$ "The Cherokee Nation, notably, only codified laws punishing rapists in the nineteenth century, after a period of close contact with white settlers." ${ }^{43}$ Even English captive narratives, for which Mary Rowlandson's The Sovereignty

\footnotetext{
${ }^{38}$ Ibid.

${ }^{39}$ Eleanor Leacock, "Montagnais Women and the Jesuit Program for Colonization," in Women and Colonization: Anthropological Perspectives. Mona Etienne and Eleanor Leacock, eds., (New York: Praeger, 1980), 31.

${ }^{40}$ Emilio and Freedman, Intimate Matters, 8.

${ }^{41}$ Ibid.

${ }^{42}$ Ibid.

${ }^{43}$ Emilio and Freedman, 9. Also, James Axtell, The Indian Peoples of Eastern America: A Documentary History of the Sexes (New York: Oxford University Press, 1981), 70-71.
}

and Goodness of God is an emblem, described relief at the tolerance and graciousness of Indian captures: "By night and day, alone \& in company, sleeping all sorts together, and yet not one of them ever offered me the least abuse of unchastity to me in word or action." ${ }^{44}$ In contrast, European invaders saw rape and pillage as a right of war. It often precipitated whitenative conflict, which presented an opportunity for whites to further evict, abuse, and control native tribes. Pushed by poverty, many Indian women chose to abandon their tribe for marriage with whites. These arrangements were often cruel and abusive. Indian trade in South Carolina as described by Theda Perdue was

replete with native complains of sexual abuse. One trader "took a young Indian against her Will for his Wife," another severely beat three women including his pregnant wife whom he killed, and a third provided enough rum to a woman to get her drunk and then "used her ill." 45

The study of mixed/multiple gender roles in Native American society occupies a distinctive prominence in anthropological scholarship. ${ }^{46}$ When Europeans first encountered men in American Indian societies "who performed the work of women, dressed like women, and had sexual relations with men," (and to a lesser degree women who switched vice versa) they labeled them with the derogatory term "berdache" (derived from an Arabic word meaning male prostitute). The term misrepresented such individuals as homosexuals and hermaphrodites while in reality, these individuals operated outside the European vision of sexuality as binary. ${ }^{47}$ Two-spirits (the non-pejorative term) had "partly or completely taken on aspects of the culturally defined role of the other sex and who are classified neither as women or men but as genders of their own." 48

This third gender variant (in the case of women who chose male-dominated occupations and roles, a fourth gender) were not merely a marginal or deviant part. On the contrary, multiple sex/gender roles constituted "a normative part of American Indian sex/gender systems," premised on "occupational aspects...[not sexual preferences] as a central feature." 49 The presence of the male two-spirit has been documented in 110 to 150 societies in North America.

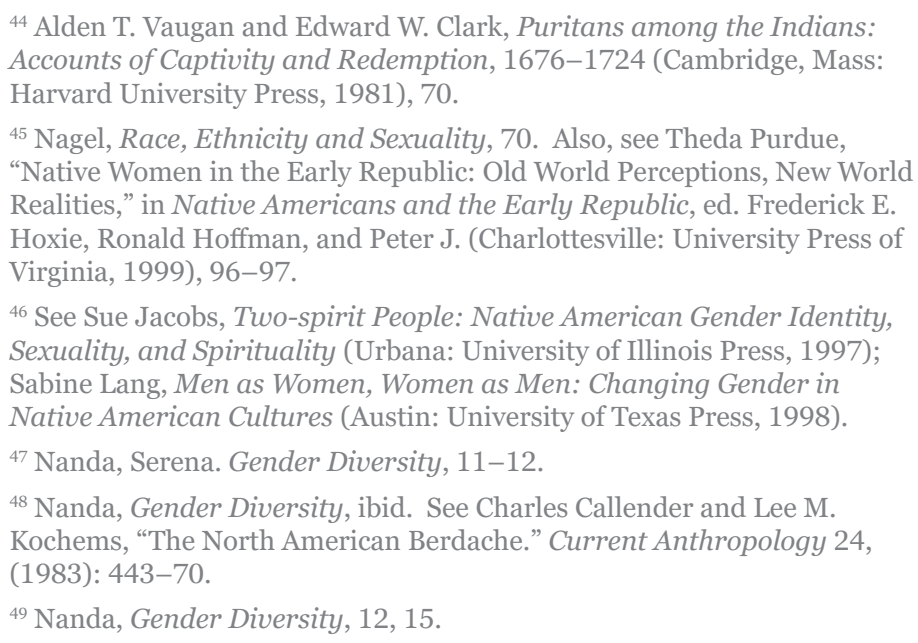
Harvard University Press, 1981), 70.

${ }^{45}$ Nagel, Race, Ethnicity and Sexuality, 70. Also, see Theda Purdue, "Native Women in the Early Republic: Old World Perceptions, New World Realities," in Native Americans and the Early Republic, ed. Frederick E. Hoxie, Ronald Hoffman, and Peter J. (Charlottesville: University Press of Virginia, 1999), 96-97.

${ }^{46}$ See Sue Jacobs, Two-spirit People: Native American Gender Identity, Sexuality, and Spirituality (Urbana: University of Illinois Press, 1997); Sabine Lang, Men as Women, Women as Men: Changing Gender in Native American Cultures (Austin: University of Texas Press, 1998).

${ }^{47}$ Nanda, Serena. Gender Diversity, 11-12.

${ }^{48}$ Nanda, Gender Diversity, ibid. See Charles Callender and Lee M. Kochems, "The North American Berdache." Current Anthropology 24, (1983): 443-70.

${ }^{49}$ Nanda, Gender Diversity, 12, 15. 
Considering the presence and exaggeration of the berdache in colonial literature from New England and the Chesapeake Bay, two-spirits most likely existed in the nations and tribes of the eastern seaboard as well before and during European settlement. ${ }^{50}$ These individuals had the advantage of an "association between the spiritual power and gender," and their often revered standing as warriors and their flexibility to take male and female sexual partners afforded gender variants a stature in Native American society unparalleled to modern attitudes toward gender non-conformists.

Perhaps unsurprisingly, Western encounters with native society that included two-spirits prompted moral outrage and misleading categorizations; Western anthropologists even into the 1970s had difficulty not romanticizing or misdefining the berdache in Western terms, "institutionalized homosexuality," transsexuals or transvestites when the actual realities of sex/ gender systems were more nuanced. ${ }^{51}$ Gender differences aided "in the construction of an enduring ethnic boundary between Indians and non-Indians," and the "sexualization of indigenous peoples...served the interests of colonial and American governments. ${ }^{" 52}$ The prevalence of captive stories, and symbolic prominence of figures such as Sacagawea reinforced a passive narrative of the indigenous as devoid of agency, a feature of the wilderness for which the American colonists were destined to conquer. However, "at the same moment, nonnatives were using imaginary native cultures and peoples to reinvent themselves as Americans" illustrated in way the white Sons of Liberty dressed as Mohawks in the 1773 Boston Tea Party and continuing to the peculiar place of Indian names (Braves, Red Skins) in American sport mascot tradition to this day. ${ }^{53}$

Among "some of the first popular publications written in the new world," ${ }^{4}$ captive narratives of nonnative women served to construct Native Americans as brutes worthy of conquering and subjugation. At the same time, they worked to preserve the sexual allure of the Other. These competing interpretations sent mixed messages to white women:

excitement, possible romantic bliss, but the chance of sexual harassment. The big, dark Indian was pictured simultaneously as a thrill and a sexual threat to white women and consequently a competitive sexual threat to white men. ${ }^{55}$

The memoirs of women such Caroline Harris, captured by Comanches in 1830 Texas, Mary Smith, captured in Kickapoos and Chickasaws in 1814, and Cooper's The Last of the Mohicans solidified the image of Indians that "ravished, rifled, murdered and mutilated the inhabitants... without any other provocation or incitement than brutal lust and wantonness of barbarity!" 56 In juxtaposition, native women were rarely described as ravished victims but as alluring nobility; the princess figure of Pocahontas stands in stark contrast to the tragic, hysterical character of someone like Jane McCrea. ${ }^{57}$ Intermarriages acquired the same ethnosexual distinction: a white woman who joined with a Native man was a sexual threat and a loss of resources, while a native woman who joined a white man reaffirmed white inheritance of North America. Mixed-blood descendants "constituted a potential pool of "middlemen" or cultural brokers between native communities...sometimes acted as 'servants of power' making deals with whites to the detriment of tribal relations." ${ }^{28}$

Current historiography gives little evidence that European colonists adopted Native American sexual practices, though there were some notable exceptions. Thomas Morton established a Plymouth plantation in 1625 in radical opposition to Winthrop's godly model of a City on a Hill.

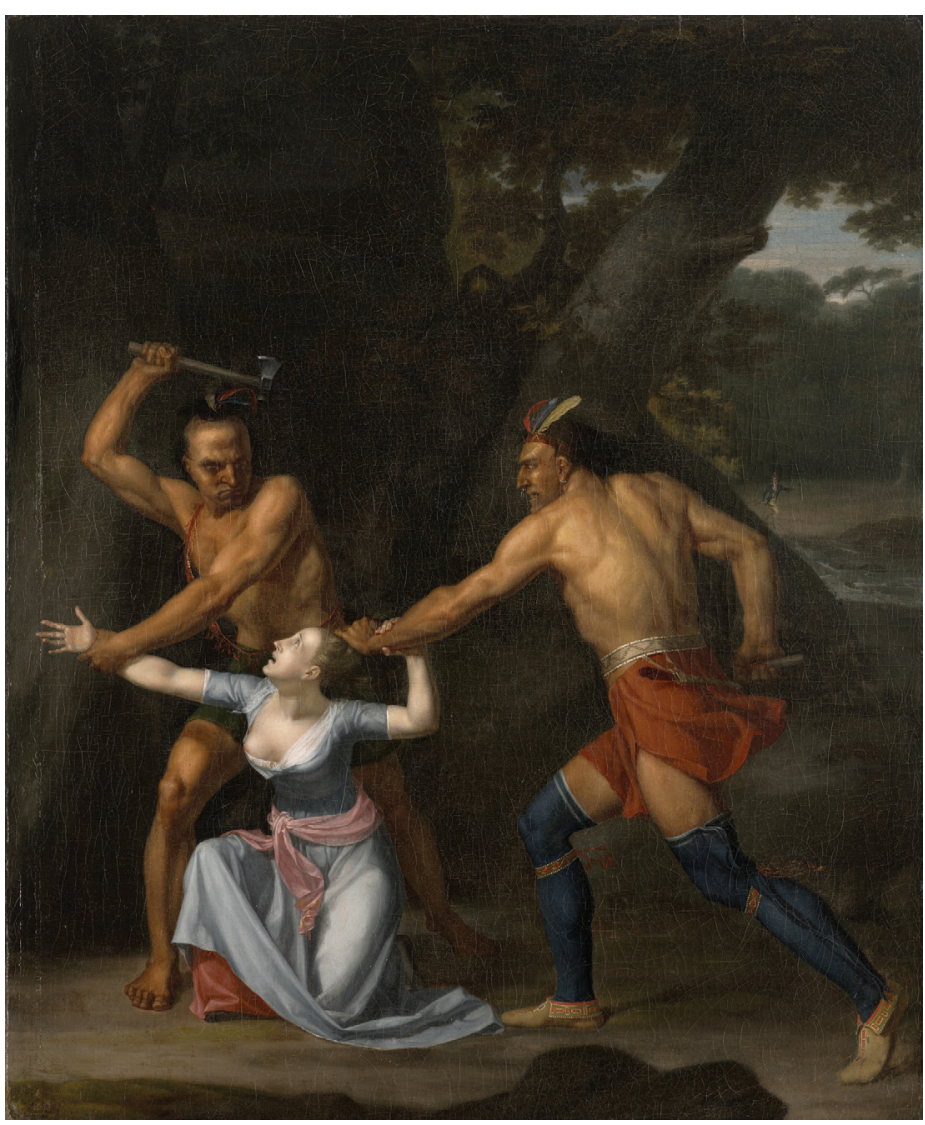

Death of Jane McCrea by John Vanderlyn, 1804

\footnotetext{
${ }^{50}$ Callendar and Kochems, "The North American Berdache," 444; Fulton, Robert, and Steven W. Anderson, “The Amerindian 'Man-Woman': Gender, Liminality, and Cultural Continuity." Current Anthropology 33, (1992): 603-10.

${ }^{51}$ Nanda, Gender Diversity, 12.

${ }^{52}$ Nagel, Race, Ethnicity, and Sexuality, 81, 83.

${ }^{53}$ Ibid. Also, see Philip Joseph Deloria, Playing Indian (New Haven: Yale University Press, 1998).

${ }^{54}$ Nagel, Race, Ethnicity, and Sexuality, 72.
}

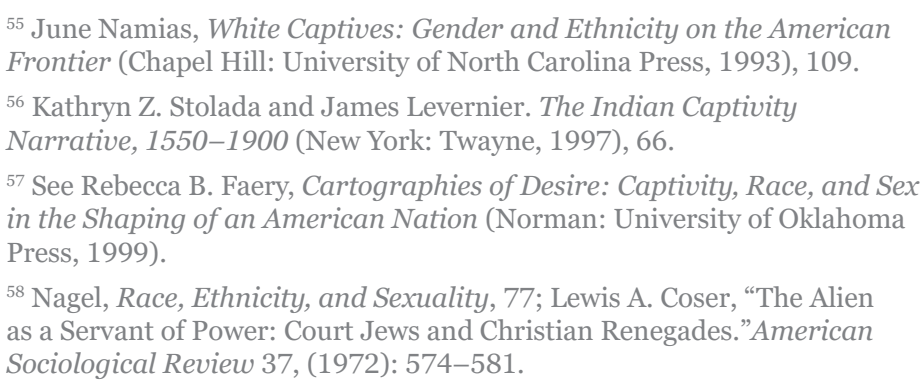

${ }^{5}$ June Namias, White Captives: Gender and Ethnicity on the American Frontier (Chapel Hill: University of North Carolina Press, 1993), 109.

${ }^{56}$ Kathryn Z. Stolada and James Levernier. The Indian Captivity Narrative, 1550-1900 (New York: Twayne, 1997), 66.

${ }^{57}$ See Rebecca B. Faery, Cartographies of Desire: Captivity, Race, and Sex in the Shaping of an American Nation (Norman: University of Oklahoma Press, 1999).

${ }^{58}$ Nagel, Race, Ethnicity, and Sexuality, 77; Lewis A. Coser, "The Alien as a Servant of Power: Court Jews and Christian Renegades.”American Sociological Review 37, (1972): 574-581. 
At the "Merry Mount," Morton and his band of followers "engaged in 'profane and dissolute living,' including sexual relations outside of marriage." He "revived the pagan May Day festivities, complete with the erotically charged maypole."59 Instead of expressing shock at native sexual habits, Morton invited them to join and had open sexual relationships. Merry Mount proved so threatening to the Pilgrim vision of social order and the Puritan family scheme that authorities tried unsuccessfully to deport him in 1628. When he returned to the Massachusetts Bay Colony, he was imprisoned and died soon after. ${ }^{60}$

Aside from the erotic appeal of pornography, Western fictions of the native brute as sexually promiscuous and violent offered "a convenient [and powerful] justification for warfare against native societies and for 'removing' Indians from areas chosen by whites for settlement." ${ }^{61}$ Captivity narratives rationalized massacres, eugenic campaigns, forceful assimilation strategies, and white responsibility for care-taking and the burdens of rule. ${ }^{62}$ Even Sacagawea, the most enduring of Native American matriarchs and a national icon, symbolized a transactional purchase and sexual exchange from frontier wilderness to the West; she acted as both a willing guide to and object of, manifest destiny. The Lewis and Clark expedition recorded her as "purchased by Toussaint Charbonneau, a trader' and subsequently impregnated-a sanitized normalization of subjugated slavery and forced marriage." ${ }^{63}$ Rebecca Faery interprets this ethnosexual exchange in her work Cartographies of Desire as a conflation of colonizers' desires for land and their desire for

a Native woman who was a representative or stand-in for the land itself; likewise, the effort to 'protect' white women from the presumed desire of dark men, both Indian and African, was a coded insistence on the rights of the colonists to territory already taken or not yet taken but desired. The history of Anglo-America, then, is a map of confluent desires, sexual and territorial, that over time produced and consolidated the map of America as we know it today. ${ }^{64}$

In these ways, sex in colonial American and the Early Republic became a sociological site to define ethno-cultural boundaries between the Indian and European settlers, reify normative mentalities, and impose a hierarchy of power to justify expansionist and assimilationist aims of white settlers. Initially, as Kathleen Brown argues, "Indian women were much more likely to be described as beautiful and alluring by [early] English writers than were their African

\footnotetext{
${ }^{59}$ Emilio and Freedman, Intimate Matters, 3.

${ }^{60}$ Emilio and Freedman, 3-4.

${ }^{61}$ Nagel, Race, Ethnicity, and Sexuality, 75.

${ }^{62}$ Sherry L. Smith, The View from Officers' Row: Army Perceptions of

Western Indians (Tucson: University of Arizona Press, 1990), 18.

${ }^{63}$ Nagel, Race, Ethnicity, and Sexuality, 75.

${ }^{64}$ Faery, Cartographies of Desire, 120.
}

counterparts." ${ }^{5}$ This focus shifted by the end of the $17^{\text {th }}$ century, when African slaves became the dominant nonwhite population in and around the American colonies. While the trope of the predatory Indian has faded from modern literary iconography, the popular fiction of the black rapist and white victim remains a trope in novella. In addition, the dark, licentious "Jezebel" supplanted the Native American woman as the sexualized Other in American culture through the course of the $19^{\text {th }}$ century, perhaps due to shifts in demography and social contact. ${ }^{66}$ As subsequent Indian wars further marginalized tribes and neutralized their political threat to the expanding Republic, slaves expanded to fill the labor force. In the public imagination, Indians were on the frontier whereas Blacks were in their backyards and fields. It is no wonder that their fantasies shifted referents.

As Puritan state regulation and disparate gender ratios faded in the course of colonial growth and immigration, "the sexual boundary between whites and black intensified." ${ }^{67}$ By the beginning of the 1700 s, when white sex ratios in the colonies had converged, sexual distinctions had reorganized along racial lines, and the ethic of marital reproduction firmly taken root. The mass importation of African slaves after 1670 and the rise of Black chattel slavery with its accompanying interracial frictions produced the sharpest distinction between the sexual dynamics of the American South and New England, where plantation slavery simply did take hold. The formation of power hierarchies between slaves/indentured servants and their masters manifested in sexual controlsboth in forced copulations, intermarriages, and sterilization procedures.

"The essence of Black women's experience during slavery was the brutal denial of autonomy over reproduction. Female slaves were commercially valuable to their masters not only for their labor but also for their ability to produce more slaves." ${ }^{8}$ In addition, the ban on international slave trade in 1808 made domestic childbearing all the more valuable, as Thomas Jefferson suggested in 1820: "I consider a woman who brings a child every two years as more profitable than the best man on the farm." ${ }^{69}$ In this way, the sexual practices of breeding and rape assumed a strong economic incentive. Slave-owners often rewarded pregnancy with relief from work, additions in clothing and food, and manipulating slave marriage choices. The womb became an "article of commerce and slave children, 'chattel'-movable property."70 Forced breeding, a controversial topic in anthropology of the

\footnotetext{
${ }^{65}$ Kathleen Brown, "Native Americans and Early Modern Concepts of Race" in Empire and Others: British Encounters with Indigenous Peoples, 1600-1850, eds. Daunton, Martin, and Rick Halpern. (Philadelphia: University of Pennsylvania Press, 1999), 91-92.

${ }^{66}$ Ibid.

${ }^{67}$ Emilio and Freedman, Intimate Matters, 38.

${ }^{68}$ Dorothy E. Roberts, Killing the Black Body: Race, Reproduction, and the Meaning of Liberty (New York: Pantheon Books, 1997), 24.

${ }^{69}$ Ibid., 25.

${ }^{70}$ Isenberg, White Trash, 41.
} 
period, is established as a documented practice, alluded to in about 5 to 10 percent of slave narratives. ${ }^{71}$ For males, similar procedures arose:

Slaveholders' interference with bonded men's intimate lives was often more than blunt. Some masters rented men of exceptional physical stature to serve as studs. Using terms such as "stockmen," "travelin' niggers," and "breedin' niggers," slave men remembered being weighed and tested, then used like animals to sire chattel for their masters. ${ }^{72}$

These inhuman practices did not develop overnight. The mass importation of African slaves to the American South began in the mid $17^{\text {th }}$ century until African slaves threatened to attain a majority in Virginia and the Old South by the end of the century. The American colonists imported their English conceptions of blacks as "lewd, lascivious and wanton people" to rationalize the formation of a separate social caste. In such a way, sex became a mechanism to determine ethno-cultural boundaries and create white, American citizenship.

Legislation criminalizing black-white sexual interactions first emerged in the 1660s: Virginia doubled fines for interracial fornication in 1662 and criminalized interracial marriages in 1691, while Maryland adopted similar antimiscegenation bans in 1664. Slavery codes included harsher punishments for interracial sexuality. However "unlike Spanish and Portuguese colonies, with their elaborate racial hierarchies in which mulatto children were often considered to be free rather than enslaved, the English colonies allowed no gradation of color." 73 Many local laws categorized race by the mother's line. South Carolina's code of 1696 and Virginia's in 1662 followed the Barbados slave code in stipulating, "All children borne in this country shall be held bond or free only according to the condition of the mother." "I4 If she were black, the child was black, no matter the father's race. This convenient rule for white predators and slave owners meant that mixed-race slaves could fetch higher prices on the market and act as middleman to enforce white slave-owners' duties. However, sexual violence, as Roberts reminds us, did not have much of a direct economic function, since rape often had a debilitating effect on a slave's productive capacities and morale. Instead, she suggests rape was "primarily a weapon of terror...designed to stifle Black women's will to resist and remind them of their servile status." 75

White males largely enforced anti-miscegenation laws only for their own women, as rape and sexual violence became another way for whites to reify dominance and control over blacks. While white women were forbidden from such interaction, "the enjoyment of a negro or mulatto woman was spoken of as quite a common thing"76 among residents,

\footnotetext{
${ }^{71}$ Ibid., 25.

${ }^{72}$ Ibid., 28.

${ }^{73}$ Emilio and Freedman, Intimate Matters, 37.

${ }^{74}$ Betty Wood, Origins of American Slavery: Freedom and Bondage in the English Colonies (New York: Hill and Wang, 1997), 92.

${ }^{75}$ Roberts, Killing the Black Body, 30.

${ }^{76}$ Ibid., 36.
}

Solomon: Sexual Practice and Fantasy

remarked a New England traveler during his visit to South Carolina. The ex-slave, African traveller Olaudah Equiano, in his writings to Western audiences, highlighted the disparity between sexual powers:

It was almost a constant practice with our clerks, and other whites, to commit violent depredations on the chastity of the female slaves...I have even known them to gratify their brutal passion with females not ten years old...And yet in Monserrat I have a seen a Negro man staked to the ground, and cut most shockingly, and then his ears cut off bit by bit, because he had been connected with a white woman who was a common prostitute; as if it were no crime in the whites to rob an innocent girl of her virtue, but most heinous in a black man only to gratify a passion of nature, where the temptation was offered by one of a different color, though the most abandoned woman of her species." 77

The double standard is well documented in legal records of the American colonies. Kathleen Brown's analysis on legal cases in colonial Virginia describe the impact of race:

"When a white woman accused a black man of rape, her chances of conviction appear to have been much higher. Of eighteen such cases to appear in Virginia's local and General Courts between 1670 and 1767, only two are known to have been dismissed. At least twelve of the nineteen accused black men were executed for their crimes." ${ }^{8}$

Although Virginia rape law ostensibly included all women, not a single recorded case of a white man prosecuted for the rape of a female slave was recorded in the entire $18^{\text {th }}$

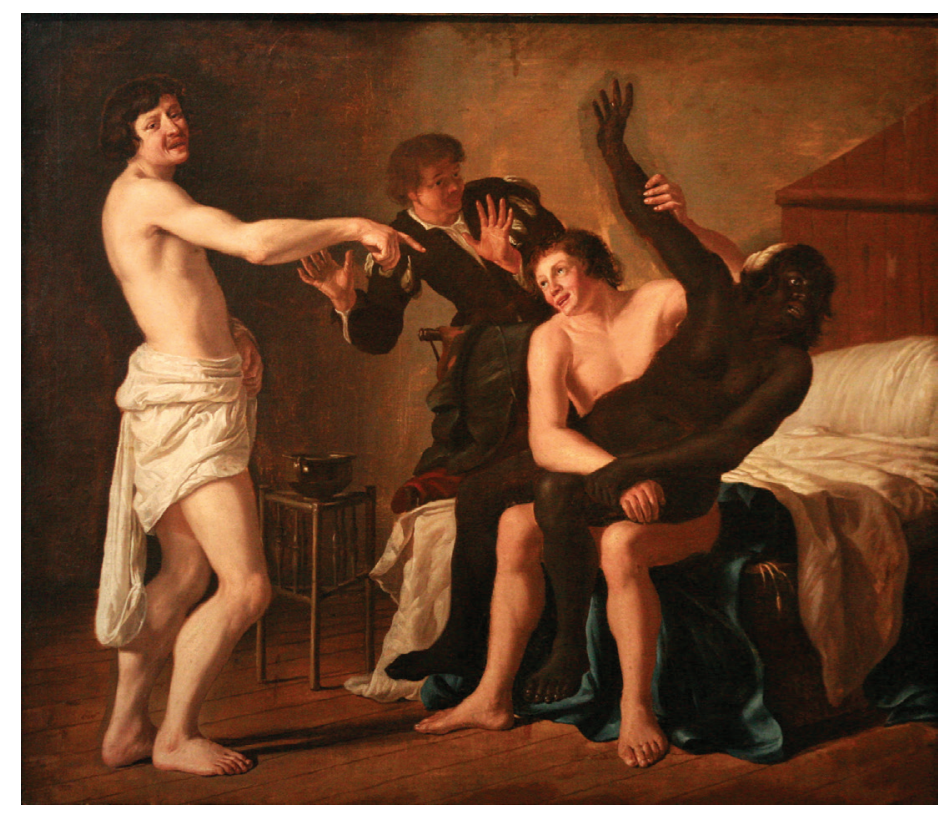

Rape of the Negro Girl by Christiaen Van Couwenbergh, 1632

${ }^{77}$ Olauda Equiano, The Interesting Narrative of the Life of Olauda Equiano, Written by Himself, ed. Robert J. Allison (Boston: St. Martin's Press, 1995), 93-94.

${ }^{78}$ Kathleen M. Brown, Good Wives, Nasty Wenches, and Anxious Patriarchs: Gender, Race, and Power in Colonial Virginia (Chapel Hill: University of North Carolina Press, 1996), 209. 
century. ${ }^{79}$ Slaves had separate criminal courts and juries, lower standards of evidence, guilty until proven innocent burdens of proof, and harsher sentencing. "Nearly two-thirds of all sexual assaults prosecuted against black men ended with a death sentence. White men, however, were likely to receive a more diverse array of punishments: only slightly more than 10 percent of their prosecutions resulted in a death sentence."80 Capital punishment was disproportionally directed at black men: "Of the 174 men known to have been executed for criminal charges related to a rape between 1700 and 1820, 142-more than 80 percent-were identified as being of African descent" despite whites outnumbering blacks in every major American region (New England, mid-Atlantic, South). ${ }^{81}$ Sharon's sociological analysis concluded, "racial identities of both victims and defendants most strongly predicted the outcome of a sexual assault prosecution." 82

Colonial legislatures-such as in Pennsylvania, New Jersey, and Virginia - created the uniquely American criminal punishment of castration as a deterrence measure. ${ }^{83}$ And while national penal codes gradually replaced capital punishment with incarceration after the American Revolution, these court systems systematically failed to include black men in those reforms. New England court systems, although officially unsegregated, still featured blacks as the overwhelming target in rape prosecutions. For example, “Connecticut's nearly complete superior court records show that...Black men accounted for more than one-third of known Connecticut rape charges from 1700 to 1820 , even though they never averaged more than 3 percent of Connecticut's population." 84 Prosecutions for black men accused of raping white women "remained surprisingly consistent in the colonial period and in the early Republic." 85 White rapists would scapegoat their black peers. As women's allegations were mistrusted, early Americans had a vested interest in concluding "that white women (practically the only legitimate victims in prosecuted rapes) would not voluntarily have sexual relations with black men, [so] black men were the most believable rapists of white women." 86

These court decisions taught colonists and early Americans to view black men as not only hypersexual, as their $17^{\text {th }}$ century ancestors promoted, but as embodying innate proclivities to sexual aggression. This evolution of ideological production had humble beginnings: "In early America, there were virtually no known lynching and comparatively few polemical treatises on black hypersexuality of the kind that appeared by the end

\footnotetext{
${ }^{79}$ Roberts, Killing the Black Body, 31. Also, Sharon Block, Rape and Sexual Power in Early America (Chapel Hill: University of North Carolina Press, 2006), 182-193.

${ }^{80}$ Block, Rape and Sexual Power in Early America, 185.

${ }^{81}$ Ibid., 99.

82 Ibid., 163-164.

${ }^{83}$ Emilio and Freedman, Intimate Matters, 36.

${ }^{84}$ Block, Rape and Sexual Power, 171.

${ }^{85}$ Ibid., 167.

${ }^{86}$ Ibid.
}

of the nineteenth century." ${ }^{77}$ No evidence can be found that black men assaulted white women in slave uprisings during the colonial period, ${ }^{88}$ and in general black men (the majority of slaves) had little ability to engage in sexual violence outside the parameters their masters ruled. However, the pressure to see blacks as vessels of evil and aggression justified the institution of slavery. Discrimination intensified after the American Revolution: repeated judicial confirmations of black men as singularly responsible, the widespread establishment of a plantation class, and the retreat of analogous threats to demonize (the Indians and the British) facilitated the rise of "widespread fear of black men's hypersexuality," rhetorical power of rape focused on blacks with full force. In this way, the myth of the black aggressor became a positive feedback loop of ideology: simultaneously validated by rape prosecutions, while also fueling them. In this way, the myth of the black rapist has undergone several transformations according to the economic and political circumstance of reigning whites.

Constructions of black sexuality and aggression were central in producing the systematic bias of early American court systems. Western fantasies of Africa as the "heart of darkness" and home to brutes and lewd orgies has been an Orientalist tradition since Shakespeare, when the Othello's portrait of the "lustful Moor" first popularized in England during the 1600s. Fascination with the Black's male genitalia also proved continuous and remains a feature of American sex culture to this day. Richard Jobson, an explorer of African societies noted in 1623 that men were "furnished with such members as are after a sort of burthensome unto them." 90 Fascination with the black penis continues, as exemplified in contemporary pornographic and erotica tropes. ${ }^{91}$

Despite the passage of much time and history since Europeans began settling North America and importing Africans to enslave for profit and profligacy, there remains in U.S. society today no ethnic boundary more sexualized or scrutinized than the color line dividing blacks and whites. ${ }^{92}$

As Dorothy Roberts details in Killing the Black Body, control of Black reproduction has remained an American tradition to the modern era. It includes the alliance of birth control activists and eugenicists in the 1920s and '30s, government-sponsored sterilization procedures in the ' $60 \mathrm{~s}$ and '70s, and the forced injection of Norplant and other contraceptives as requirements to receive welfare even into the '90s.

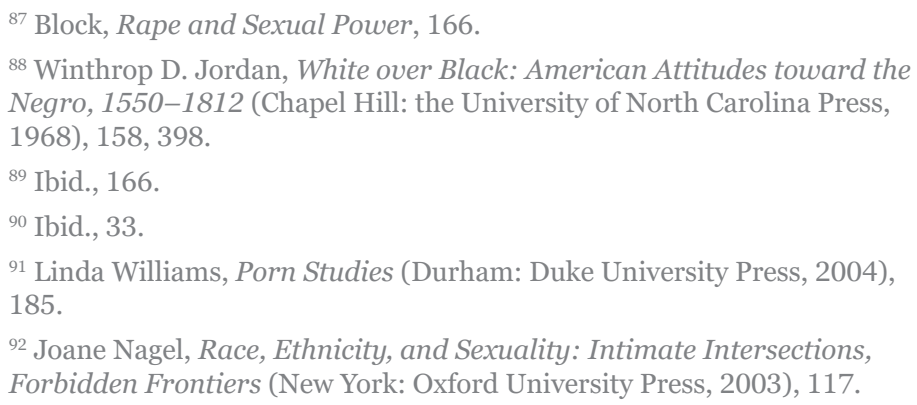

${ }^{88}$ Winthrop D. Jordan, White over Black: American Attitudes toward the Negro, 1550-1812 (Chapel Hill: the University of North Carolina Press, 1968), 158, 398.

${ }^{89}$ Ibid., 166.

${ }^{90}$ Ibid., 33.

${ }^{91}$ Linda Williams, Porn Studies (Durham: Duke University Press, 2004), 185.

${ }^{92}$ Joane Nagel, Race, Ethnicity, and Sexuality: Intimate Intersections, Forbidden Frontiers (New York: Oxford University Press, 2003), 117. 
The longevity of black rapist and white victim tropes in novella demonstrates the continued salience of these sexualized boundaries. While the image of the native woman has receded in popular reference as the sexualized Other, depictions of the dark Jezebel remain immediately recognizable in American culture. It is important to realize these fictions had political motivations and sexually reflected the dominance of the more powerful race. The creation of a strong, sexually competitive black male in Western discourse gave more gratification to see it vanquished. It also functioned to shock white women and possible deviators into racial conformity. To sexualize the African woman and deny her agency rationalized white supremacy; it was easier to sexually exploit people when they were seen as "always wanting it" or easily persuaded. Sex thus became a site to manifest the formation of racial hierarchies, formulate American citizenship, and enforce whites' dominance. These hierarchies relied on violence for their endurance.

As Oscar Wilde observed, "Everything in the world is about sex except sex. Sex is about power." Such an intersection is both striking and helpful for understanding the political narratives and practices of early American colonists and peoples. From this analysis, someone like Samuel Terry "chafing his yard to provoak lust," the myth of the Black rapist, or the sale of Sacagawea can be contextualized in the political and social forces of the time period. I hope to have demonstrated that sexuality is a salient social platform on which historical power dynamics between groups are established and reaffirmed and that prevailing political and social forces of the time can explain its broader sexual dynamics. Specifically, I have demonstrated how colonial women leveraged their unique role as mothers and breeders to secure their access to worth in society, how sexuality informed and mapped class divisions and family relations between early American whites, how the fictions of native sexuality informed American myths of manifest destiny, and how rape and other sexual controls aided white supremacy and justified slavery. Finally, I showed how sex became a site to build racial hierarchies and formulate citizenship. The legacy of these boundaries still carries through to today. In this way, historical analysis of family politics, class divisions, and national myths provides important insights into the history of American sexuality.

\section{AUTHOR INFORMATION}

All correspondence should be sent to the first author: ricsolom@indiana.edu.

\section{BIBLIOGRAPHY}

Axtell, James. The Indian Peoples of Eastern America: A Documentary History of the Sexes. New York: Oxford University Press, 1981.

Bergon, Frank. The Journals of Lewis and Clark. New York: Penguin Books, 1989.
Block, Sharon and Brown, Kathleen M. "Clio in Search of Eros: Redefining Sexualities in Early America." William and Mary Quarterly 60, (2003). 5-12.

Block, Sharon. Rape and Sexual Power in Early America. Chapel Hill: University of North Carolina Press, 2006.

Brown, Kathleen M. "Native Americans and Early Modern Concepts of Race." In Empire and Others: British Encounters with Indigenous Peoples, 1600-1850, ed. Daunton Martin, and Rick Halpern. Philadelphia: University of Pennsylvania Press, 1999.

Brown, Kathleen M., and Va. Williamsburg. Good Wives, Nasty Wenches, and Anxious Patriarchs: Gender, Race, and Power in Colonial Virginia. Chapel Hill: University of North Carolina Press, 1996.

Callender, Charles, and Kochems, Lee M. "The North American Berdache." Current Anthropology 24, (1983): 443-70.

Tomlins, Christopher L. Freedom Bound. Law, Labor, and Civic Identity in Colonizing America, 1580-1815. Cambridge: Cambridge University Press, 2010.

Coser, Lewis A. "The Alien as a Servant of Power: Court Jews and Christian Renegades."American Sociological Review 37, (1972): 574.

Davis, Jack L. and Berkhofer, Robert F. The White Man's Indian: Images of the American Indian from Columbus to the Present. New York: Vintage Books, 1979.

Deloria, Philip Joseph. Playing Indian. New Haven: Yale University Press, 1998.

Demos, John. A Little Commonwealth: Family Life in Plymouth Colony. 2. New York: Oxford University Press, 1970.

Detweiler, Robert. "Shifting Perspectives on the Salem Witches.” The History Teacher 8 (1975): 596-610.

Emilio, John and Freedman, Estelle B. Intimate Matters: A History of Sexuality in America. New York: Harper \& Row, 1988.

Faery, Rebecca Blevins. Cartographies of Desire: Captivity, Race, and Sex in the Shaping of an American Nation. Norman: University of Oklahoma Press, 1999.

Fessenden, Tracy. The Puritan Origins of American Sex: Religion, Sexuality, and National Identity in American Literature. New York: Routledge, 2001. 
Fulton, Robert and Anderson, Steven W. "The Amerindian "Man-Woman": Gender, Liminality, and Cultural Continuity." Current Anthropology 33, no. 5 (1992): 603-10.

Innes, Stephen. Labor in a New Land Economy and Society in Seventeenth-Century Springfield. Princeton: Princeton University Press, 2014.

Jacobs, Sue. Two-spirit People: Native American Gender Identity, Sexuality, and Spirituality. Urbana: University of Illinois Press, 1997.

Jordan, Winthrop D., and Va. Williamsburg. White over Black: American Attitudes toward the Negro, 15501812. Chapel Hill: University of North Carolina Press, 1968.

Lang, Sabine. Men as Women, Women as Men: Changing Gender in Native American Cultures. Austin: University of Texas Press, 1998.

Luker, Kristin. Abortion and the Politics of Motherhood. Berkeley: University of California Press, 1984.

Nagel, Joane. Race, Ethnicity, and Sexuality: Intimate Intersections, Forbidden Frontiers. New York: Oxford University Press, 2003.

Namias, June. White Captives: Gender and Ethnicity on the American Frontier. Chapel Hill: University of North Carolina Press, 1993.

Isenberg, Nancy. White Trash: The 400-Year Untold History of Class in America. New York: Random House, 2016.

Nanda, Serena. Gender Diversity: Crosscultural Variations. Prospect Heights, Illinois: Waveland Press, 2000. Print.

Norton, Mary Beth. "Gender and Defamation in Seventeenth-Century Maryland." William and Mary Quarterly 44 (1987): 3-39.

Equiano, Olauda. The Interesting Narrative of the Life of Olauda Equiano, Written by Himself, ed. Robert J. Allison. Boston: St. Martin’s Press, 1995.

Roberts, Dorothy E. Killing the Black Body: Race, Reproduction, and the Meaning of Liberty. New York: Pantheon Books, 1997.

Said, Edward. Culture and Imperialism. New York: Random House, 1993.
Slater, Sandra. "Sex and Sin: The Historiography of Women, Gender, and Sexuality in Colonial Massachusetts." Historical Journal of Massachusetts 41, (2013): 104-135.

Smith, Sherry L. The View from Officers' Row: Army Perceptions of Western Indians. Tucson: University of Arizona Press, 1990.

Stodola, Kathryn Zabelle, and Levernier, James. The Indian Captivity Narrative, 1550-1900. New York: Twayne, 1997.

Stoler, Ann Laura. Race and the Education of Desire: Foucault's History of Sexuality and the Colonial Order of Things. Durham: Duke University Press, 1995.

Weisberg, K. Kelly. “'Under Greet Temptations Heer' Women and Divorce in Puritan Massachusetts." Feminist Studies 2 (1975): 183-193.

Williams, Linda. Porn Studies. Durham: Duke University Press, 2004.

Wood, Betty. The Origins of American Slavery: Freedom and Bondage in the English Colonies. New York: Hill and Wang, 1997. 
